\title{
On Conceptual and Methodological Deficiencies of Data Journalism-Related Studies in Turkey
}

\section{Türkiye'de Veri Gazeteciliği ile İlgili Çalışmalardaki Kavramsal ve Metodolojik Eksiklikler}

\author{
Ilgar SEYIDOV ${ }^{1 \oplus}$
}

${ }^{1}$ Asst. Prof. Dr., Atılım University, School of Business, Public Relations and Advertising, Ankara, Turkey

ORCID: 0000-0001-8420-1413

Sorumlu yazar/Corresponding author: Ilgar Seyidov,

Atılım Üniversitesi, İşletme Fakültesi, Halkla İlişkiler ve Reklamcılık Bölümü,

Ankara, Türkiye

E-posta/E-mail: ilgar.seyidov@atilim.edu.tr

Geliş tarihi/Received: 06.11.2019 Revizyon talebi/Revision Requested: 11.02.2020

Son revizyon teslimi/Last revision

received: 16.04 .2020

Kabul tarihi/Accepted: 14.05.2020

Online yayın/Online published: 10.07.2020

Atıf/Citation: Seyidov, I. (2020). On conceptual and methodological deficiencies of data journalism-related studies in Turkey. Connectist: Istanbul University Journal of

Communication Sciences, 58, 273-289.

https://doi.org/10.26650/CONNECTIST2020-0070

\begin{abstract}
The Internet and technological developments have brought profound changes in social, cultural, and political structures worldwide. These changes have influenced not only the formal background, but also contextual frame of those structures. Perhaps no field has been more affected than media. The Internet and Web 2.0 technologies have led to the formation of new media platforms- digital media tools. Massive collections of data, search engines, and complex data services have emerged. Thus, the term "Big Data" has become widespread worldwide. Much research has been conducted to understand how various disciplines make use of and benefit from big data. In this context, media and communication scholars have focused on this newest concept in terms of effective data use and interpretation of complex information in practice. Big Data has become a keyword in contemporary journalism studies. The use of various data sets, graphics, complex charts, figures, and advanced techniques in news making and presentation has been discussed within the framework of data journalism since the late 2000s worldwide. The current study aims to find out how data journalism has been conceptualized in Turkey, and what are the inadequacies that need to be developed. To this end, data journalism-related studies were subjected to content analysis. The findings showed that there is still lack of conceptualization of data journalism and comprehensive research in Turkey.
\end{abstract}

Keywords: Big data, media, data journalism, content analysis, Turkey

öz

İnternet ve teknolojik gelişmeler beraberinde sosyal, kültürel ve siyasi değişimleri de getirmiştir. Bu değişimler toplumsal yapıları sadece biçimsel olarak değil aynı zamanda içeriksel olarak da derinden etkilemiştir. En fazla etkilenen yapılardan biri de medyadır. Özellikle bu anlamda yeni medya platformlarının yanı sıra, büyük ölçekli bilgi ve enformasyon depoları, arama motorları ve benzeri veri ağları örnek 
gösterilebilir. "Büyük veri" kavramı bu şekilde dünya çapında fenomen bir kavram haline gelmiştir. Kavramı anlamak ve bu sistemden etkili yararlanabilmek için çok sayıda araştırma yürütülmektedir. Medya ve iletişim çalışmalarında ise büyük veri etkili veri kullanımı ve karmaşık bilgi ağlarının yorumlanması çerçevesinde ele alınmaktadır. Özellikle gazetecilik alanında büyük veri 2000'li yıllardan itibaren önemli araştırma konularından biri haline gelmiştir. "Veri gazeteciliği" önemli bir iletişim alanına dönüşmektedir.
Bu çalışma, Türkiye'de de yeni bir kavram ve alan olan veri gazeteciliğinin nasıl kavramsallaştırıldığını ele almaktadır. Amaçsal örneklem kapsamında konu ile ilgili ulaşılan çalışmalar içerik analizi ile incelenmiştir. Elde edile bulgular, kavramsallaştırmanın hala tam olarak yapılamadığı ve ilgili çalışmaların yeterli düzeyde olmadığına işaret etmektedir.

Anahtar Kelimeler: Büyük veri, medya, veri gazeteciliği, içerik analizi, Türkiye

\section{INTRODUCTION}

The advent of computer systems, the Internet, and Web 2.0 technology has paved the way for the emergence of both big and complex data sets, and easy access to a huge amount of information and a variety of data sets. In this context, the term 'Big Data' has become a phenomenon in the natural and social sciences.

Within the scope of strict computing terminology, big data has come to mean data sets which exceed the memory of standard computer and software processes. Due to an increase in the volume, variety, and velocity of the data, current technology remains incapable of coping with the storage and processing of the data (Lewis, \& Westlund, 2015 , p. 448). This includes various online transactions, videos, images, audio, emails, click streams, posts, search engines and inquiries, science data, sensors, and applications. All of these are stored in a database system which is likewise expanding progressively and massively. It is the variety and scale that render the data as "Big". Therefore, big data is now a focal topic of modern science and research in different fields. Simply put, the great variety of sources are included in big data (Sağıroğlu, \& Sinanc, 2013, pp. 42-43).

On account of its massive capacity to store information, it is impossible to analyze all the data. The challenge stems mainly from the dimensions of big data such as abundance, variety, timeliness, dynamism, messiness, high rationality, and uncertainty. However, this multi-dimensional structure also provides opportunities for scholars to develop more sophisticated, wider scale scientific models (Kitchin, 2014, pp. 2-7).

Along with its above-mentioned technological definitions and attributes, big data is also a social and cultural phenomenon that allows analysis of large data sets to identify patterns in social, economic, and legal claims. Furthermore, it can generate 
insights about the aura of truth, objectivity, and accuracy (Lewis, \& Westlund, 2015, p. 449). These components are vital to media as well. Therefore, big data has led to formation of new concepts and understanding within media studies. The ability to access huge sets of data prompted journalists to apply the big data system to contemporary journalism practices. The data cultures have penetrated the epistemology of journalism, which blurred the distinctions between reporting and programming, storytelling and coding, hypothesis-driven inquiry and data-driven inquiry, journalistic thinking and computational thinking, interactivity and staticity, human-focused and machine-focused paradigms (Rey-Borges, 2017, p. 2). As a result of this convergence between data and journalism, a new term "data journalism" emerged by the late 2000s. It is a generally accepted phenomenon allowing the use of data effectively in journalism. However, beyond this simple understanding, its structure is much more sophisticated.

Using data and visualization in news reporting is not utterly new. It can be traced back to two centuries ago, in an issue of The Guardian in 1821. The data depicted the numbers of pupils attending school in England. The aim was to describe the education system in the country. In 1851, Florence Nightingale also used data visualization including diagrams, charts, and tables of data in her report concerning the mortality of the British Army. Following that century, the use of statistical information, data tables, figures, various charts, and other visualization data became prevalent in journalism (Kalatzi, Charalampos, \& Veglis, 2018, p. 36).

For Royal and Blassingame (2015, pp. 25-26), the origin of "data journalism" is rooted in graphic design and computer-assisted reporting. They supported Edward Tufte's idea that excellence in statistical graphics was based on clarity, precision, and efficiency. Referring to this idea, the authors described data journalism as the presentation of information online with an interactive component allowing customization and use of data for the users. This is also essential for populating graphics with dynamic information. For Uskali and Kuutti $(2015$, p. 78), WikiLeaks's secret data sets can be considered as the starting point for contemporary journalism activities. The Afghan and Iraq War logs and the US Embassy cited examples of other materials used in initial data journalism activities in their study. For Knight (2015, p. 56), the term "data journalism" appeared in 2008, in the article by Simon Rogers in the The Guardian. It was described as the combination of two older news practices: Infographics and Computer-Assisted reporting (CAR). Infographics, which is the production of graphs, charts, maps, and other factual illustrations, traces back to the 19th Century. Whereas, CAR dates back to the 1980s 
and the growth of personal computers. Data journalism is not only about the interpretation of data charts or systems. There are many other characteristics of data journalism specified by scholars worldwide.

There is no generally accepted definition of data journalism among scholars globally. For Kalatzi, Charalampos and Veglis (2018, p. 37), data journalism has become one of the effective means of media in terms of transparency. Datasets can be seen and checked by audiences as they are reliable sources beyond the story. Therefore, data journalism is a new form of journalism that has been evolving consistently. It combines numerical data from multiple sources in the production and distribution of information in the digital era. Most importantly, the data is both the source and tool of information (Veglis, \& Bratsas, 2017, p. 3).

Data journalism includes a variety of ways to gather news as a process, output, or set of skills (Bradshaw, 2015, p. 203). This variety makes data journalism distinct from traditional journalism in that it combines the traditional "nose for news" with digitalized information. In this way, data journalism helps journalists to narrate very complicated stories using various data sets or infographics readily (Gray, Bounegru, \& Chambers, 2012, p. 2).

The conceptualization and methodology of data journalism remains problematic and uncertain. Since the late 2000s, many studies have been conducted to explore the theoretical background and practical structure of data journalism in a comprehensive way. Some of the research focused on the issue of conceptualization of data journalism (Bradshaw, 2015; De Maeyer et al., 2015; Borges-Rey, 2017; Staph, \& Borges-Rey, 2018), and some analyzed different practices (Knight, 2015; Fink, \& Anderson, 2015; Loosen, Reimen, \& Schmidt, 2015; Tandoc, \& Oh, 2017; Appelgren, 2018; Zamith, 2019).

Bradshaw's (2015) research, which aimed to find out what ethical principles can be aligned within data journalism, addressed specific issues such as accuracy, data gathering and reporting, context, interactivity, privacy, protection of sources, and methodology. De Maeyer and her colleagues (2015) conducted 20 semi-structured interviews with experts who contributed to the development of data journalism in Belgium. The research examined the qualitative characteristic of data journalism to discover common themes and the definition of data journalism. However, the results presented were full of contrasts. News organizations have different approaches to the understanding of data journalism. While Borges-Rey (2017) emphasized an epistemological framework for 
data journalism in the United Kingdom through a literature review, Staph and BorgesRey (2018) problematized sustainability of data journalism by conducting in-depth interviews with three groups of key-informants. In his research, Borges-Rey (2017, p. 15) found that data journalism in the devolved nations of Scotland, Northern Ireland, and Wales in the United Kingdom "legitimizes its knowledge claims by amplifying the existing distinctive epistemological character of the news media of these regions". The research of Staph \& Borges-Rey (2018) concluded that data journalism in the United Kingdom diversified into three forms which are brief, investigative, and gamified.

On the other hand, Knight (2015) examined the use of data in Sunday newspapers in the United Kingdom. By using content analysis, the author analyzed 112 newspapers in total. In particular, news, lifestyle, and entertainment sections were included in the sampling. According to the results, The Guardian newspaper showed more commitment to data journalism, and more complex data. In order to examine the computational journalism practices, Fink and Anderson (2015) conducted semi-structured interviews with 23 journalists who worked at the online-only news sites of newspapers. The relation between the professional experiences/educational backgrounds of the participants, and data journalism was evaluated. In addition, the reporting and producing of data stories were analyzed in the research. Their research concluded that the production of data journalism was stratified between resource-rich and resource-poor organizations in countries like the United States and Norway. Similarly, Loosen, Reimen, and Schmidt (2015) examined various outputs of data journalism such as data sources and types, visualization strategies, interactive features, topics, and types of media outlets within the sampling through content analysis. They found that data journalism as a reporting style included political topics based on official sources. Furthermore, the use of pictures with simple charts or maps was preferred in the news. Tandoc and Oh (2017) employed quantitative content analysis to analyze online big data journalism stories in The Guardian's Datablog. They found that the markers of traditional news can also be widely seen in the practice of big data journalism. While the aim of Appelgren's (2018) research was to explore how paternalism manifested in data journalism through the content analysis of 31 elected data journalism projects, the study of Zamith (2019) examined the websites of the New York Times and The Washington Post over a six-month period. In total, 159 articles were analyzed by means of quantitative content analysis. The study of Appelgren (2018) found that data journalism projects with paternalistic elements usually included physical interactivity at a low level. On the other hand, the research of Zamith (2019) concluded that content was typically produced by small teams, and 
focused on "hard news,"This news also provided non-complex data visualizations with low levels of interactivity.

As can be seen in the above-mentioned studies and research, no specific definition of data journalism was commonly accepted or emphasized. In general, the effective use of data and information was mentioned. As to research methods, in-depth interviews and content analysis were commonly used in the studies. In Turkey, although the concept of "big data" has been widely analyzed in various disciplines, data journalism has not been analyzed adequately. During the literature review, only 14 studies were accessed as the comprehensive research focused specifically on data journalism. The current study aims to find out how data journalism was conceptualized, what the main issues were, and which research techniques were used in those studies. In this context, it is believed that, this study will contribute to the related literature in terms of understanding the conceptual and methodological deficiencies of data journalismrelated studies in Turkey.

\section{AIM AND METHODOLOGY}

Within the framework of this study, the conceptualization and methodological issues of data journalism in Turkey were questioned. In this vein, this research aimed to find out how data journalism in Turkey was conceptualized and which methodology was preferred in the related studies. In doing so, four main research questions were identified as follow:

- How was Data Journalism conceptualized in the academic studies and research?

- Which issues were the main focuses of the studies?

- Which methodological tools were used in the studies?

- What suggestions can be useful for the development of data journalism in Turkey?

By focusing on the above-stated research questions, content analysis approach was selected as the research technique to analyze the findings. The selection of the content analysis was related to its capacity to identify as having both qualitative and quantitative characteristics. This research technique is widely described as a comprehensive and systematic analysis of quantitative and qualitative data of specific themes (Cohen, Manion, \& Morrison, 2007). It allows the researcher to explore the contextual and formal structure of any kind of selected material in an objective way (Aziz, 1994, p. 119; Gökçe, 
2006, p. 17). Content analysis is a deductive research method that provides both qualitative and quantitative explorations through categorization and classification (Bilgin, 2006, p. 1).

Based on purposive sampling, first, the terms "büyük veri,"'very gazeteciliği,"'data journalism," and "veri haberciliği" in Turkish were explored on search engines and at the Thesis Center Council of Higher Education. Then, only "data journalism" related studies were selected for sampling. In total, 14 studies were identified in this way. Only academic studies and research published in peer-reviewed journals, books, conference papers, or dissertations were included in the sampling.

Following the selection of sampling, content analysis was employed to analyze the findings qualitatively. In total, five main categories were identified as relevant to thematic categorization. In doing so, research questions were prioritized. The essential details of any sort of study were tackled starting with conceptual background to research methods used. To this end, all of the related information was scrutinized under specific schemes and by using tables. All the tables and quantitative information was also interpreted qualitatively. The qualitative aspect of the research technique allowed us to analyze the qualitative data in a detailed way.

In the research, intercoder reliability tests were conducted by the author. The codebook was revised, and categories which did not meet the criteria were removed. In the end, only 14 studies were analyzed. The selected papers were coded by the author and controlled by a professional researcher. For reliability, $7 \%$ of the papers $(n=1)$ were chosen randomly and were coded by both researchers (two researchers) separately to check the levels of agreement between two independent coders. Accordingly, the final results of intercoder reliability were rational to accept.

\section{FINDINGS}

Within the scope of this research, five main categories were identified: General Overview of the Studies, Conceptual Framework of Data Journalism, The Research Subjects, The Research Methods Used in the Studies, and Suggestions. By using content analysis, five main tables and one figure were prepared in order to demonstrate the findings clearly and comprehensively. The related tables were illustrated under the section of "Tables and Figures." All the tables were numbered relevant to the categories. 


\section{General Overview of the Studies}

The first category focused on a general overview of the studies examining data journalism. For this category, "date of issue," "the departments of the authors," and "published in" are the focal points to understand the development of data journalism research in Turkey. This allowed us to find out which departments focused on the concept and when the research began. In accordance with Table 1, it shows that data journalism has been a focal topic starting in 2015. However, as can be seen in Figure 1 , the majority of studies were released or published in 2018. As to the distribution of studies, Journalism was the top department that analyzed data journalism. Out of the 14 studies accessed, three were theses, two were book chapters, eight were papers published in peer-reviewed journals, and one was a conference paper. However, a sharp decline was observed in 2019 compared to 2018. While there were nine studies in 2018, only one study was published in 2019. In addition, it was possible to include the 10-month period between January and October in the sampling. It is also possible that some of the studies might have been published in December issues of journals.

\section{Conceptual Framework of Data Journalism}

Within the scope of this category, the research focused on how the concept, data journalism, was defined in the studies. The analysis revealed four common definitions that can be seen in Table 2 . The majority of studies (57\%) defined data journalism as news/narrative formed through the use of various data sets, online reporting, and similar advanced techniques. In this scope, what differentiates data journalism from traditional journalism was the integration of complex charts, tables, and figures in order to produce more objective information. On the other hand, $21 \%$ of the studies underlined data journalism as a new type of journalism. According to those studies, this type of journalism allowed audiences to understand big data sets easily. Therefore, one key mission of data journalism is to analyze complex charts, tables and such clearly and comprehensively. Table 2 demonstrates that $14 \%$ of the studies described data journalism as a digital brand of investigative journalism. As such, the inevitable role of big data in the development of investigative journalism was also mentioned. Similar to the framework of the first definition, $8 \%$ of the studies also stressed the use of multiple data sets. However, unlike the first ones, these studies dwelled specifically on the possibility of obtaining reliable information through data journalism practices. 


\section{The Research Subjects}

Under this category, the research subjects of the studies were analyzed. The main purpose was to discover which main topics and issues were mentioned in the scope of data journalism. As can be seen in Table 3, in total, seven main sub-categories were identified. Amongst them, the contextual construction of data journalism practices was discussed predominantly as the share of $30 \%$ in the distribution of topics. In addition, a general understanding of data journalism was evaluated in $21 \%$ of the studies through a literature review. According to Table 3, while $14 \%$ of the studies underlined the need to use data in terms of media development, another $14 \%$ of the total problematized the relationship between data journalism and democracy and transparency was based on the dissemination of objective information. The role of Infographics in effective communication of the news was emphasized in only one study, yielding a share of 7\% (Table 3). Finally, while 7\% of studies discussed professional skills and ethics in data journalism, another $7 \%$ alluded to the historical development of data journalism in Turkey.

\section{Research Methods Used in the Studies}

In order to understand how data journalism-oriented studies analyzed their main topics and research subjects, Table 4 was prepared using content analysis. In total, eight different sub-categories of research methods were identified in the selected studies. Amongst them, a literature review, the technique used in four studies, was preferred. The research methods in three studies were determined as undefinable due to the lack of any explanation or section about methodology. However, they may be considered as a literature review as well. A Descriptive Analysis technique was employed in only two studies. In the remaining five studies, the authors employed methodologies such as questionnaires, content analysis, document analysis, semi-structured interviews, and target audience analysis. As can be seen in the Table 4, the majority of studies applied to a literature review.

\section{Suggestions}

In this last category, the results of the selected studies about data journalism were examined. The aim was to find out what the studies concluded from the findings and what they suggested for further research. As can be seen in Table 5 , in total, four different 
sub-categories were identified. Half of the studies (50\%) agreed that data journalism was necessary for providing objective information and data. This was also considered an attribute that sets data journalism apart from traditional journalism. On the other hand, the lack of educational and professional job skills was underlined by $30 \%$ of the studies. In this respect, those studies emphasized the development of these deficiencies. While the positive effect of using infographics in news formation was mentioned by $14 \%$ of the studies, $7 \%$ concluded that Twitter was a useful and helpful platform for data journalism practices in terms of promotion and information dissemination.

\section{DISCUSSION AND CONCLUSION}

Data journalism is one of the newest phenomenon that has emerged and developed since the advent of Big Data. This concept has led to formation of a new epistemological background of journalism based on synthesized understanding between human and machine-focused paradigms. Different from traditional journalism, data journalism is defined as an innovative form of information processing and news formation. However, there is still a lack of research on the conceptualization and implementation of data journalism in the world, and particularly in Turkey. The current study aimed to find out how data journalism has been conceptualized by studies in Turkey, what the main issues specified, and what suggestions could be useful to advance the state of research and contribute to the development of this field.

The research findings showed that most issue-related studies were released or published in 2018. However, the volume of such studies declined drastically in 2019. Only one study in 2019 was found after a thorough detailed search. On the other hand, three theses were released in 2018 that could be considered comprehensive research for data journalism in the country. The other publications were either presented at a conference or published in peer-reviewed journals, excluding two book chapters. Considering that data journalism was already a phenomenon by 2000 s, there was a great need to conduct a comprehensive literature review, case studies, and analyses of specific examples in Turkey.

As to conceptual framework of data journalism, it was shown that the concept was mainly defined as news/narrative formation by means of various data sets, and similarly advanced techniques. In this vein, the aim of data journalism was identified to make a variety of big data sets understandable for audiences. This conceptual framework is 
similar to Bradshaw's (2015) definition that data journalism includes as great variety of data sets and skills to be used in information processing and news formation. This aim corresponds to Gray, Bounegru and Chambers's (2012) emphasis on the elucidatory role of data use in complex narratives and news.

The majority of the studies focused on contextual construction of data journalism practices in Turkey. They emphasized the capacity of data journalism to provide transparent and objective information. This idea was also argued by other studies worldwide as mentioned before. Veglis and Brastas (2017) linked this idea to data being both a source and tool of information. Therefore, data sets can be checked by audiences clearly (Kalatzi, Charalpas, \&Veglis, 2018). Although professional skills, general principles, and the importance of data use were examined through a literature review and descriptive analysis technique, none of the studies scrutinized data journalism practices or examples using other quantitative or qualitative methods preferred in international literature. For instance, Loosen, Reiner \& Schmidt (2015) employed a content analysis technique in order to explore visualization strategies, interactive features, media outlets, ecetera. In the same manner, Tandoc and Oh (2017) also used quantitative content analysis to analyze online big data journalism stories in The Guardian's Datablog. Further research may focus specifically on data journalism examples and news in Turkey. In this context, case study analysis, content, and framing analysis could be useful research methods to explore data journalism practices more comprehensively.

Concerning the recommendations for the development of data journalism, most studies concluded that there was a need to develop the educational and professional background of journalists. The majority of studies depicted journalism as providing objective information under certain conditions. However, none of those studies mentioned the sustainability of this possibility given the abundance of disinformation. Above all, none of the studies touched upon the ethical principles in order to discuss objectivity in a comprehensive way.

Consequently, the findings of study showed that the term data journalism and the related concepts were ill-defined in the selected studies. Moreover, the research techniques used in the studies were not effective to analyze the specific issues or details with regard to data journalism practices. In this respect, Bradshaw's (2015) study can be a good example as analyzing the accuracy, data gathering and reporting in data journalism. While for sustainability problem of data journalism the study of 
Staph and Borges-Rey (2018) can provide important suggestions, Knight's (2015) comprehensive work can give detailed information about the use of data in newspapers. By referring to Fink and Anderson's (2015) study, the comprehensive research can be conducted about professional backgrounds of data journalists. This will allow finding out how to develop data journalism in terms of theoretical and practical aspects. The other gap in the data journalism-related studies is the lack of studies, which are focused on analysis of data sources types, visualization strategies, and interactive features of media outlets. In this context, Loosen, Reimen and Schmidt's (2015) can be directive for the future studies.

This study revealed that there was a lack of comprehensive studies and research analyzing data journalism in Turkey. Such detailed studies and research could contribute to the development of data journalism both theoretically and practically in the country. Different sections of online newspapers and various news types may be appropriate to analyze. In doing so, the use of content analysis or other techniques which involve both qualitative and quantitative characteristics could be a more effective research methodology than a literature review on its own. This study is believed to be a directive for further research to explore the gaps and areas lacking in data journalism research in Turkey.

Peer-review: Externally peer-reviewed.

Conflict of Interest: The authors has no conflict of interest to declare.

Grant Support: The authors declared that this study has received no financial support.

\section{REFERENCES}

Appelgren, E. (2018). An illusion of interactivity. Journalism Practice, 12(3), 308-325. https://doi.org/10.1080/175 12786.2017.1299032

Aslan, A., Bayrakçı, S., \& Küçükvardır, M. (2016). Bilişim çağında geleneksel gazeteciliğin dönüşümü: Veri gazeteciliği. Marmara Illetişim Dergisi, 26, 55-70. https://doi.org/10.17829/midr.2017.44

Atalay, E.G. (2018). Enformasyon arayışı ve gazeteciliğin dönüşümü: Panama belgeleri. Avrupa Sosyal ve Ekonomik Araştırmalar Dergisi, 5(5), 143-157.

Aziz, A. (1994). Araştırma Yöntemleri-Teknikleri ve Illetişim. Ankara, Turkey: Turhan Kitabevi. Bayraktar, G. (2018). Türkiye'de veri gazeteciliği: Medya profesyonellerinin veri gazeteciliği algısı üzerine bir araştırma (MA Thesis). Available from Council of Higher Education's Thesis Center (UMI No. 502509).

Bilgin, N. (2006). Sosyal Bilimlerde Içerik Analizi. Ankara, Turkey: Siyasal Kitabevi. 
Borges-Rey, E. (2017). Towards an epistemology of data journalism in the devolved nations of the United Kingdom: Changes and continuities in materiality, performativity and reflexivity. Journalism. https://doi. org/10.1177/1464884917693864

Bradshaw, P. (2015). Data journalism. In L. Zion, \& D. Graig (Eds.), Ethics for Digital Journalists: Emerging Best Practices (pp. 202-223). New York, USA: Routledge.

Can, S., Koz, A. K., \& Işık, V. (2018). Use of infographics in data journalism. The Journal of International Civilization Studies, 3(2), 156-171. https://doi.org/10.26899/inciss.169

Cohen, L., Manion, L., \& Morrison, K. (2007). Research Methods in Education. New York, USA: Routledge Falmer. Çelik, T. (2017). Changing data journalism understanding: Data journalism. In E. Doğan, \& E. Geçgin (Eds.), Current Debates in Public Relations, Cultural \& Media Studies (pp. 169-183). London, UK: IJOPEC Publication.

Çetin, B. (2018). Geleceğin teknolojileri ve gazetecilik mesleği üzerine etkileri: Büyük veri, veri gazeteciliği, yeni yaklaşımlar. In O. Uçak (Ed.), Dijital Medya ve Gazetecilik (pp. 31-63). Konya, Turkey: Eğitim Yayınevi.

De Maeyer, J., Libert, M., Domingo, D., Heinderyckx, F., \& Le Cam, F. (2015). Waiting for data journalism. Digital Journalism, 3(3), 432-446. https://doi.org/10.1080/21670811.2014.976415

Doğu, B. (2015). Veri haberciliği: Demokratik medya için olanaklar. Folklor/Edebiyat, 21(83), 181-197.

Erkmen, Ö. (2018). Büyük veri ve gazetecilik: Veri gazeteciliği demokrasi, katılım ve gazeteciliğe dair anlayışımızı nasıl dönüştürebilir? Akdeniz Üniversitesi Illetişim Fakültesi Dergisi, 30, 322-344.

Erol, S. (2018). Türkiye'de veri haberciliğini etkileyen unsurların analizi (MA Thesis). Available from Council of Higher Education's Thesis Center (UMI No. 518436)

Erol, S., \& Işıklı, S. (2019). Türkiye'de veri haberciliği üzerine bir değerlendirme. ISophos, 2(2), 143-163.

Fink, K., \& Anderson, C. W. (2015). Data journalism in the United States. Journalism Studies, 16(4), 467-481. https:// doi.org/10.1080/1461670X.2014.939852

Genel, G. M., Sayar, E. T., \& Sayar, B. (2018). Veri gazeteciliğinin gelişimine yönelik bir değerlendirme. International Conference on Data Science and Application Proceedings (pp. 73-84). Yalova, Turkey: Yalova University Press.

Gray, J., Bounegru, L., \& Chambers, L. (2012). The Data Journalism Handbook. Sebastopol: O'Reilly Media.

Gökçe, O. (2006). Içerik Analizi: Kuramsal ve Pratik Bilgiler. Ankara, Turkey: Siyasal Kitabevi.

Kalatzi, O., Charalampos, B. \& Veglis, A. (2018). The principles, features, and techniques of data journalism. Studies in Media and Communication, 6(2), 36-44. https://doi.org/10.11114/smc.v6i2.3208

Kitchin, R. (2014). Big data, new epistemologies, and paradigm shifts. Big Data \& Society. https://doi. org/10.1177/205395171452848

Knight, M. (2015). Data journalism in the UK: A preliminary analysis of form and content. Journal of Media Practice, 16(1), 55-72. https://doi.org/10.1080/14682753.2015.1015801

Kürkçü, D. D. (2018). Veri gazeteciliği: Gazeteciliğin ve gazetecilerin geleceği. Anadolu Üniversitesi Illetişim Bilimleri Fakültesi Uluslarararsı Hakemli Dergisi, 26(3), 101-116.

Lewis, S. C., \& Westlund, O. (2015). Big data and journalism. Digital Journalism, 3(3), 447-466. https://doi.org/10.1 $080 / 21670811.2014 .976418$ 
Loosen, W., Reimen, J., \& Schmidt, F. (2015). When data become news: A content analysis of data journalism pieces. Paper presented at The Future of Journalism: Risks, Threats and Opportunities. Cardiff University, UK.

Narin, B., Ayaz, B., Fırat, F., \& Fırat, D. (2017). Büyük veri ve gazetecilik ilişkisi bağlamında veri gazeteciliği. AJIT-e: Online Academic Journal of Information Technology, 8(30), 215-235. https://doi.org/10.5824/1309-1581.2017.5.010.x

Oran, I. (2018). A Qualitative Analysis of Data Journalism in Turkey (MA Thesis). Available from Council of Higher Education's Thesis Center (UMI No. 497288).

Royal, C., \& Blasingame, D. (2015). Data journalism: An explication. The Official Research Journal of the International Symposium on Online Journalism, 5(1), 24-47.

Sağıroğlu, S., \& Sinanc, D. (2013). Big data: A review. In 2013 International Conference on Collaboration Technologies and Systems (pp. 42-47), San Diego, USA.

Stalph, F. (2018). Classifying data journalism. Journalism Practice, 12(10), 1332-1350. https://doi.org/10.1080/175 12786.2017.1386583

Stalph, F., \& Borges-Rey, E. (2018). Data journalism sustainability. Digital Journalism, 6(8), 1078-1089. https://doi. org/10.1080/21670811.2018.1503060

Tandoc, E. C., \& Oh, S. (2017). Small departures, big continuities? Journalism Studies, 18(8), 997-1015. https://doi. org/10.1080/1461670X.2015.1104260

Uskali, T., \& Kuuti, H. (2015). Models and streams of data journalism. The Journal of Media Innovations, 2(1), 77-88.

Veglis, A., \& Bratsas, C. (2017). Reporters in the age of data journalism. Journal of Applied Journalism \& Media Studies, 6, 225-244. https://doi.org/10.1386/ajms.6.2.225_1

Zamith, R. (2019). Transparency, interactivity, diversity, and information provenance in everyday data journalism. Digital Journalism, 7(4), 470-489. https://doi.org/10.1080/21670811.2018.1554409 


\section{TABLES AND FIGURES}

Table 1: General Overview of the Studies

\begin{tabular}{|c|c|c|c|c|c|}
\hline Number & Author(s) & $\begin{array}{l}\text { Date of } \\
\text { Issue }\end{array}$ & Department & Title of Paper & Published in \\
\hline 1 & Burak DOĞU & 2015 & $\begin{array}{c}\text { Media \& } \\
\text { Communication }\end{array}$ & $\begin{array}{l}\text { Data Journalism: } \\
\text { Opportunities for } \\
\text { Democratized Media }\end{array}$ & $\begin{array}{l}\text { Folklor \& Edebiyat } \\
\text { Journal }\end{array}$ \\
\hline 2 & $\begin{array}{l}\text { Alaattin } \\
\text { ASLAN, Serkan } \\
\text { BAYRAKÇI, Mert } \\
\text { KÜÇÜKVARDAR }\end{array}$ & 2016 & Journalism & $\begin{array}{c}\text { Conversion of } \\
\text { Traditional Journalism } \\
\text { in the Age of } \\
\text { Information: } \\
\text { Data Journalism }\end{array}$ & $\begin{array}{c}\text { Marmara Journal of } \\
\text { Communication }\end{array}$ \\
\hline 3 & $\begin{array}{l}\text { Bilge NARIN, } \\
\text { Bahar AYAZ, } \\
\text { Feyyaz FIRAT, } \\
\text { Demet FIRAT }\end{array}$ & 2017 & Journalism & $\begin{array}{l}\text { Data Journalism in the } \\
\text { Context of Big Data } \\
\text { and Journalism }\end{array}$ & $\begin{array}{c}\text { AJIT-E: Online Academic } \\
\text { Journal Of Information } \\
\text { Technology }\end{array}$ \\
\hline 4 & Tolga ÇELIKK & 2017 & Journalism & $\begin{array}{c}\text { Changing Journalism } \\
\text { Understanding: Data } \\
\text { Journalısm }\end{array}$ & Book Chapter \\
\hline 5 & $\begin{array}{c}\text { Gökhan } \\
\text { BAYRAKTAR }\end{array}$ & 2018 & Journalism & $\begin{array}{l}\text { Data Journalısm in } \\
\text { Turkey: A Study on } \\
\text { Data Journalısm } \\
\text { Perceptıon of Medıa } \\
\text { Professıonals }\end{array}$ & $\begin{array}{c}\text { MA Thesis, Marmara } \\
\text { University }\end{array}$ \\
\hline 6 & Sedat EROL & 2018 & Journalism & $\begin{array}{l}\text { The Analysis of Factors } \\
\text { Impacting on Data } \\
\text { Journalism in Turkey }\end{array}$ & $\begin{array}{c}\text { MA Thesis, Marmara } \\
\text { University }\end{array}$ \\
\hline 7 & Duygu D. KÜRKÇÜ & 2018 & Journalism & $\begin{array}{l}\text { Data Journalism: The } \\
\text { Future of Journalism } \\
\text { and Journalists }\end{array}$ & $\begin{array}{c}\text { Anadolu University } \\
\text { Communication Journal }\end{array}$ \\
\hline 8 & İrem ORAN & 2018 & New Media & $\begin{array}{c}\text { A Qualitative Analysis } \\
\text { of } \\
\text { Data Journalism } \\
\text { Practice in Turkey }\end{array}$ & $\begin{array}{c}\text { MA Thesis, Kadir Has } \\
\text { University }\end{array}$ \\
\hline 9 & Özlem ERKMEN & 2018 & $\begin{array}{l}\text { Communication } \\
\text { Sciences }\end{array}$ & $\begin{array}{c}\text { Big Data and } \\
\text { Journalism: How } \\
\text { Data Journalism Can } \\
\text { Transform Our } \\
\text { Understanding } \\
\text { of Democracy, } \\
\text { Participation, and } \\
\text { Journalism? }\end{array}$ & $\begin{array}{c}\text { Akdeniz Communication } \\
\text { Journal }\end{array}$ \\
\hline 10 & $\begin{array}{l}\text { Serap CAN, Umur } \\
\text { IŞIK, Konur Alp } \\
\text { KOZ }\end{array}$ & 2018 & Journalism & $\begin{array}{l}\text { Use of Infographics in } \\
\text { Data Journalism }\end{array}$ & $\begin{array}{l}\text { The Journal of } \\
\text { International } \\
\text { Civilization Studies }\end{array}$ \\
\hline 11 & $\begin{array}{c}\text { Mehmet Gökhan } \\
\text { GENEL, Tahsin } \\
\text { Eren SAYAR, Banu } \\
\text { EZBER }\end{array}$ & 2018 & $\begin{array}{l}\text { Communication } \\
\text { Sciences }\end{array}$ & $\begin{array}{l}\text { An Evaluation of } \\
\text { Data Journalism } \\
\text { Development }\end{array}$ & $\begin{array}{l}\text { Conference/ } \\
\text { Proceedıngs }\end{array}$ \\
\hline
\end{tabular}




\begin{tabular}{|c|c|c|c|c|c|}
\hline 12 & Belgin ÇETIN & 2018 & Media & $\begin{array}{c}\text { The Future } \\
\text { Technologies and } \\
\text { Effects on Journalism } \\
\text { Profession: Data } \\
\text { Journalism, New } \\
\text { Approaches }\end{array}$ & Book Chapter \\
\hline 13 & Gül Esra ATALAY & 2018 & $\begin{array}{c}\text { New Media \& } \\
\text { Journalism }\end{array}$ & $\begin{array}{c}\text { Anarchy of Information } \\
\text { and Transformation of } \\
\text { Journalism: Panama } \\
\text { Documents }\end{array}$ & $\begin{array}{c}\text { Eurasian Journal of } \\
\text { Researches in Social and } \\
\text { Economics }\end{array}$ \\
\hline 14 & $\begin{array}{c}\text { Sedat EROL, Şevki } \\
\text { IŞIKLI }\end{array}$ & 2019 & Journalism & $\begin{array}{c}\text { An Evaluation on The } \\
\text { Data Journalism in } \\
\text { Turkey }\end{array}$ & $\begin{array}{c}\text { ISophos: International } \\
\text { Journal of Information, } \\
\text { Technology and } \\
\text { Philosophy }\end{array}$ \\
\hline
\end{tabular}

Figure 1: Number of Studies

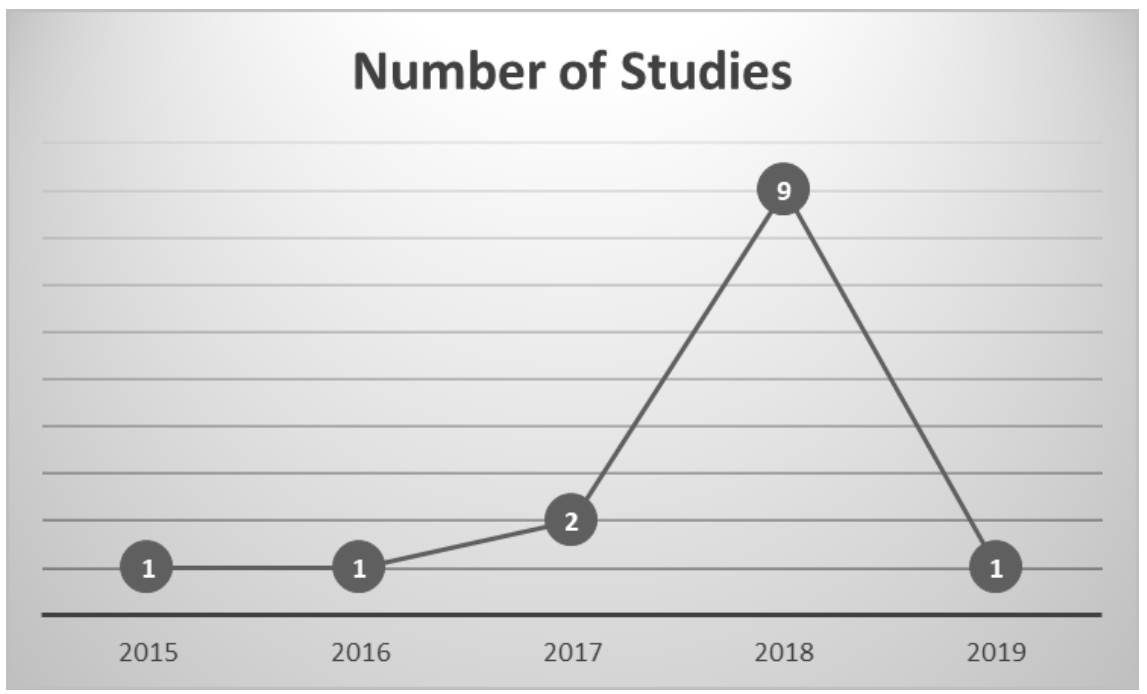

Table 2: Conceptual Framework of Data Journalism

\begin{tabular}{|l|c|c|}
\hline The Main Definitions & Number & Percentage \\
\hline $\begin{array}{l}\text { News/narrative formation using of various data sets, online reporting, and } \\
\text { similar advanced techniques }\end{array}$ & 8 & $57 \%$ \\
\hline $\begin{array}{l}\text { A new type of journalism that renders big data sets understandable for the } \\
\text { audiencies }\end{array}$ & 3 & $21 \%$ \\
\hline An investigative journalism digitalized by data and its practices. & 2 & $14 \%$ \\
\hline A reliable journalism type processing data and information objectively & 1 & $8 \%$ \\
\hline TOTAL & $\mathbf{1 4}$ & $\mathbf{1 0 0 \%}$ \\
\hline
\end{tabular}


Table 3: Categorization of the Research Subjects

\begin{tabular}{|l|c|c|}
\hline The Main Topics & Number & Percentage \\
\hline The Contextul Construction of Data Journalism Practices & 4 & $30 \%$ \\
\hline The Understanding of Data Journalism & 3 & $21 \%$ \\
\hline Professional Skills in Data Journalism & 1 & $7 \%$ \\
\hline The Use of Infographics & 1 & $7 \%$ \\
\hline The Importance of Data Use in Media & 2 & $14 \%$ \\
\hline The Relation of Data Journalism with Transperancy and Democracy & 1 & $14 \%$ \\
\hline The Historical Development of Data Journalism in Turkey & 1 & $7 \%$ \\
\hline TOTAL & $\mathbf{1 4}$ & $\mathbf{1 0 0 \%}$ \\
\hline
\end{tabular}

Table 4: Research Methods Used in the Studies

\begin{tabular}{|l|c|c|}
\hline Research Method & Number & Percentage \\
\hline Literature Review & 4 & $\mathbf{3 0} \%$ \\
\hline Descriptive Analysis Technique & 2 & $14 \%$ \\
\hline Undefined & 3 & $21 \%$ \\
\hline Questionnaire & 1 & $7 \%$ \\
\hline Content Analysis & 1 & $7 \%$ \\
\hline Document Analysis & 1 & $7 \%$ \\
\hline Semi-Structured Interview & 1 & $7 \%$ \\
\hline Target Audience Analysis & 1 & $7 \%$ \\
\hline TOTAL & $\mathbf{1 4}$ & $\mathbf{1 0 0 \%}$ \\
\hline
\end{tabular}

Table 5: Conclusions \& Suggestions

\begin{tabular}{|l|c|c|}
\hline Results & Number & Percentage \\
\hline $\begin{array}{l}\text { Data Journalism is/can be effective in providing objective information or } \\
\text { data }\end{array}$ & 7 & $50 \%$ \\
\hline $\begin{array}{l}\text { Education and Job Professionalism should be developed in Data Journalism } \\
\text { in Turkey }\end{array}$ & 4 & $29 \%$ \\
\hline Infographics is essential for inreasing the effectiveness of news & 2 & $14 \%$ \\
\hline Twitter is an useful platform for data journalism practices & 1 & $7 \%$ \\
\hline TOTAL & $\mathbf{1 4}$ & $\mathbf{1 0 0 \%}$ \\
\hline
\end{tabular}


